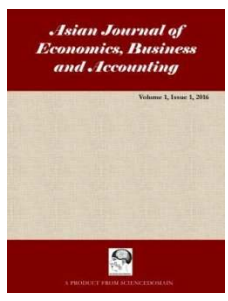

\title{
Impact of International Public Sector Accounting Standards (IPSAS) Adoption on Financial Accountability in Selected Local Governments of Oyo State, Nigeria
}

\author{
O. Ademola, Abimbola ${ }^{1^{*}}$, A. Adegoke, Kolawole ${ }^{2}$ and A. Oyeleye, Olufunke ${ }^{3}$ \\ ${ }^{1}$ Department of Management and Accounting, Ladoke Akintola University of Technology (LAUTECH), \\ Ogbomoso, Oyo State, Nigeria. \\ ${ }^{2}$ Department of Accounting, Achievers University, Owo, Ondo State, Nigeria. \\ ${ }^{3}$ Department of Accounting, Adeleke University, Ede, Osun State, Nigeria.
}

Authors' contributions

This work was carried out in collaboration between all authors. Author OAA designed the study and wrote the protocol while author $A A K$ wrote the first draft of the manuscript and the literature searches. Author AOO analysed the data. All authors read and approved the final manuscript.

Article Information

DOI: $10.9734 / A J E B A / 2017 / 33866$ Editor(s):

(1) Maria-Dolores Guillamon, Department of Financial Economics and Accounting, University of Murcia, Spain. Reviewers:

(1) Ciurea Maria, University of Petrosani, Romania. (2) B. N. Swami, University of Botswana, Gaborone, Botswana. (3) Elżbieta Szczepankiewicz, Uniwersytet Ekonomiczny W Poznaniu, Katedra Rachunkowości, Poland. Complete Peer review History: http://www.sciencedomain.org/review-history/19331

Original Research Article

Received $1^{\text {st }}$ May 2017

Accepted 24 ${ }^{\text {th }}$ May 2017

Published $3^{\text {rd }}$ June 2017

\begin{abstract}
The study evaluated the impact of International Public Sector Accounting Standard (IPSAS) on the financial accountability of selected local governments of Oyo State, Nigeria. The impact of IPSAS adoption on corruption reduction, transparency and accountability in the selected Local Governments were critically examined. The study which adopted survey design collected data using five point likert-scale questionnaires which was administered on sample of 105 Accountants and Internal Auditors in the selected local governments of Oyo State Nigeria.

The data was analyzed using descriptive statistics. The hypotheses formulated were tested using chi-square analysis at $5 \%$ level of significance. The result of the study showed that adoption of IPSAS increases the level of accountability, transparency and reduces corruption in the selected local governments. This implied that the economy of Nigeria will be better off if IPSAS is fully adopted and implemented.
\end{abstract}


Having seen IPSAS as the agents of the needed change in Nigeria, the study recommends that Nigerian government should enact an enabling law to back up the adoption and implementation of IPSAS and more importantly institute appropriate sanctions to ensure full compliance.

Keywords: IPSAS; financial accountability; corruption; transparency; local governments.

\section{INTRODUCTION}

Accountability in the midst of mistrust and dishonesty in handling public fund is a serious issue which bedeviled the Nigerian public sector. Most successive administrations at the Federal, State and Local Government always lay emphasis on the problem of corruption, misappropriation and non-accountability. Despite numerous laws and relevant institutions that exist in Nigeria, there has been significant increase in the number of reported cases of all kinds of misappropriation of public funds and properties.

Evidences abound that public funds in Nigeria are misappropriated and not well utilized. For instance, the Police Pension scandal, a fraud of over N40 billion pension scam of N5.6 billion involving Oyo State Head of Service [1], \$1.6 million bullet proof BMW car in the Aviation Ministry [2], the former Petroleum Minister, Alison Maduekwe money laundering issue, just to mention a few. Moreover, the Federal, State and especially the Local government levels are faced with the challenges of transparency and accountability in their cash-based accounting and budgeting systems. [3] further butressed this assertion by reporting that cases of fraud is prevalent in the Nigeria public sector and every segment of the public service seem to be involved in one way or the other.

As a result of increasing demand for greater transparency and accountability in management of public finances, most governments all over the world have resolved to reform their government financial management systems and processes. It was in response to this challenge that the International Federation of Accountant (IFAC) through "International Public Sector Accounting Standard Board" (IPSASB) came up with "International Public Sector Accounting Standard" (IPSAS) of public affairs in the country [4]

The introduction of IPSAS formed an important part of public sector reforms and is a centrepiece of the global revolution in government accounting and in response to calls for greater government financial accountability and transparency $[5,6]$. IPSAS ensures high standards which serve as catalyst for the preparation of sound and transparent financial statements. This in turn improves operational performance, accountability and efficient allocation of resources.

In fact, IPSAS is operationalized to provide accurate and comprehensive accounting information with a view to demonstrating appreciable level of accountability, stewardship and credibility. This entail providing interested parties with unambiguous and comprehensive information regarding the financial consequences of the economic, political and social activities of government [7].

Furthermore, Adebayo [8] noted that IPSAS ensures good financial practices with the capability of disclosing financial irregularities swiftly within the public sector irrespective of the size of such public institution. In order to have a good picture of IPSAS and its implications on public sector accounting, this study therefore seeks to examine the impact of IPSAS adoption on financial accountability in selected local government areas of Oyo State.

\subsection{Statement of the Problem}

The role of the local governments as a veritable instrument for rapid development of rural and urban areas can not be under estimated. They are strategically located to play a pivotal role in national development. However, it is observed that the numerous local governments in Nigeria are entrenched with corruption, lack of accountability and transparency orchestrated by cash basis of accounting. Therefore, in order to reduce corruption to the barest minimum, IPSAS was introduced in order to ensure a holistic reporting of government's financial transaction and position. Several governments have introduced IPSASs because it is considered to be good and timely. According to [9] while some adopt the standard wholesomely, others adopt and modify the standard. 
Despite the benefits derivable from its adoption, [5] contended that the adoption of IPSAS is expensive in all material respect, such that its much advertised benefits do not justify the cost of its implementation. Thus, it is not quite established whether the adoption and subsequent proper implementation of IPSAS would have appreciable positive or negative impacts on the Nigerian economy. Therefore, this study seeks to evaluate the impact of IPSAS on financial accountability of selected local governments in Oyo State, Nigeria.

\subsection{Objectives of the Study}

The broad objective of the study is to evaluate the impact of IPSAS on financial accountability of selected local governments in Oyo State, Nigeria. While the specific objectives of the study are to:

- Determine the impact of IPSAS adoption on corruption reduction in the selected local Governments of Oyo state and

- Examine the effect of IPSAS adoption on transparency and accountability in the selected Local Governments of Oyo State.

\subsection{Hypotheses of the Study}

The study formulated and tested the following hypotheses:

${ }^{1} \mathrm{H}_{\mathrm{O}}$ : IPSAS adoption does not reduce corruption in selected local governments of Oyo State,

${ }^{2} \mathrm{H}_{\mathrm{O}}$ : IPSAS adoption does not enhance transparency and accountability in selected local governments of Oyo State, Nigeria.

\section{LITERATURE REVIEW}

\subsection{Conceptual Issues}

\subsubsection{Conceptual framework of IPSAS}

The development of the IPSAS has its origin in the accounting progression as a way to improve the transparency and accountability of governments and their agencies by improving and standardizing financial reporting. The IPSAS Board (IPSASB) is an independent standard setting board supported by the International Federation of Accountants (IFAC). The IPSASB issues IPSAS, guidance and other resources for use by the public sector around the world.
The IPSASB (and its predecessor, the IFAC public sector committee) has been developing and issuing accounting standards for the public sector since 1997 [10]. As transactions are generally common across both the private and public sector, there has been an attempt to have IPSAS converged with the equivalent International Financial Reporting Standards (IFRS).

The IPSAS are also developed for financial reporting issues that are either not addressed by adopting an IFRS or for which no IFRS has been developed. According to [11] cited in [12], most of the IPSAS are based on accrual basis which is in line with IFRS. The IPSASB started out with the conceptual framework of the International Accounting Standards Boards (IASB) and is in the process of developing its own conceptual framework to meet the financial reporting needs of entities in the public sector.

The public sector, for the purpose of IPSAS, refers to national government, regional governments (e.g state, provincial and territorial), local government (e.g town and city), and related government entities (e.g agencies, boards, commissions and enterprises). The IPSAS applied in the preparation of general purpose financial reports that are intended to meet the needs of users who cannot otherwise command reports to meet their specific information needs [13]. IPSAS are aimed for application to the general purpose financial reporting of all public sector entities other than Government Business Enterprises (GBEs). GBEs are expected to apply IFRS [14].

\subsubsection{Countries that have adopted IPSAS}

The increasing demand of high quality global financial reporting standards of public entities brought to the fore the craze for adoption of IPSAS by both the developing and developed countries. According to [8], the countries that have adopted IPSAS are grouped as follows:

\subsubsection{Countries that have fully adopted and implemented IPSAS}

Abu Dhabi, Albania, Australia, Azerbaijan, Bangladesh, Brazil, Canada, Cayman Islands, Cyprus, Costa Rica, East Timor, Fiji, France, Georgia, Japan, Kazakhstan, Kyrgyzstan, Latvia, Liberia, Lithuania, Malaysia, New Zealand, Nicaragua, Pakistan, Palestine, Philippines, Romania, Russia, Singapore, Slovak Republic, 
Solomon Islands, Spain, Sri Lanka, Switzerland, Tanzania, Turkey, United Kingdom, Uruguay, and Uganda.

\subsubsection{Countries that are in the process of IPSAS adoptions}

Yemen, Vietnam, Zambia, Zimbabwe, Vanuatu, Argentina, Armenia, Barbados, Afghanistan, Argentina, Cambodia, China, Estonia, Gambia, Guatemala, Honduras, Jamaica, Mauritania, Mauritius, Namibia, Peru, Swaziland, Ghana and Nigeria.

However, a review of the process of adoption and post IPSAS adoption and implementation in some countries such as New Zealand, South Africa, Brazil, Canada and Australia unveiled that IPSAS adoption and implementation by those countries increased efficiency and supported long-term planning and execution of policies and programmes in the country. The implementation also provided members of the legislatures, ministers, and other authorities of governments with more information for informed decision making $[15,16,17]$.

\subsubsection{IPSASs adoption towards transparency and accountability}

The global trends of event have informed both the private and public sectors on the need to address matters that bother on Transparency and Accountability. Without doubt transparency and accountability is all about being responsible to those who have invested their trust, confidence and resources to one in assigned position or office. According to Adegite[18] cited by [19], defined Accountability as the obligation to demonstrate that work has been conducted in accordance with agreed rules and standards and the officers reports fairly and accurately on performance results vis-à-vis mandated roles and plans.

[20] says that public accountability is an essential component for the functioning of our political system. [21] viewed public accountability as the basic tenet of democracy. [22] seen it to be the duty to truthfully and transparently do ones duty and the obligation to allow access to information by which the quality of such services can be evaluated and being responsible and answerable to someone for some action.

Similarly, the principle of transparency relates to the openness of government to its citizens. Good governance includes appropriate disclosure of key information to stakeholders so that they have the necessary facts about the government's performance and operations. Accordingly, the government's decisions, actions and transactions are conducted in the open [23]. In relating IPSAS adoption on Transparency and accountability, the UNAIDs programme committee board (2013) reported that IPSAS adoption will improve transparency and accountability of the financial report. [24] pointed out that IPSAS are standards of high quality which serve as catalyst for providing sound and transparent financial statements thereby improving operational performance, accountability and fair allocation of resources

[5] observed IPSAS standards to improve transparency and accountability in government entity's financial report. The development of the IPSAS has its origins in the accounting profession as a way to enhance the transparency and accountability of governments and their agencies by improving and standardizing financial reporting. Finally, [25] concluded that there are no doubts that applying universal high quality standards can promote efficiency, transparency which in long-run may promote public accountability.

\subsubsection{IPSAS adoption towards corruption reduction}

Over the years, citizens of some developing countries have been blaming and accusing their leaders of mismanagement and diversion of public resources for their personal gains. While some members of the public describe the ugly menace as stealing, others term it corruption[26]. It was in this direction that [27] observed that adoption and proper implementation of IPSAS would create avenue for reduction in case of manipulation of financial resources in the public sector since one of the objectives of IPSASs is to engender transparency and accountability in the operation of public entities. It was also added that full and proper implementation of IPSAS pave way for Related Party Disclosure which by extension check cases of corruption through effective, efficient, and transparent financial reporting in the public sector [28].

Considering the fact that official corruption is a threat to government legitimacy and authority and reduces the amount of public money available to fund public services, adoption and implementation of IPSASs by the accounting profession are giant steps in the global fight against government corruption [5]. 


\subsection{Theoretical Framework}

This study is anchored on Commander theory which was propounded in 1965 by Louis (Lou) Goldberg in course of his work titled "Inquiry into the Nature of Accounting" at Australia. It is one of the accounting theories that provides a strategic platform through which financial report disclosure activities is recognized. Commander theory constitutes a theoretical foundation and basis upon which the analysis of the impact of a crosssector transfer of accounting principles and rules to the public sector is based.The assumption of the theory has it that owner(s) of resources may also be the controller/director of the resources, but in some cases, separation between the control and ownership prevails.

Where separation exists between the ownership and control of the resources, command is bestowed on the controller who has power and authority to direct the affairs of the institution while the owner(s) in turn, demands reports and accountability from the controller. The theory in respect to government sees top public office holders- such as ministers, special advisers, permanent secretaries etc. as commanders at the top level of a hierarchy of command who should be accountable to the state for the resources entrusted in their control through annual financial statement. Head of departments and directors who carry out the directives of ministers in their respective departments should also be accountable of the resources at their disposal to the relevant authorities which at the end of the period will be aggregated to form consolidated financial statements comprehensive enough to permit informed judgment by the financial information users.

This theory becomes essentially relevant considering the fact that IPSASs advocate for full disclosure of financial information to enable interested financial information users take informed judgement. If full disclosure of public sector financial transactions is made, it would pave way for credibility and comparability which would lead to transparency of government financial and non-financial activities.

\section{METHODOLOGY}

\subsection{Population of the Study}

The study was carried out in Oyo sate, Nigeria. It is an inland state in South -Western Nigeria and was formed in 1976, bounded in the North by Kwara state, in the east by Osun state, in the South by Ogun State and in the West partly by Ogun State and partly by the Republic of Benin [29]. The state is made up of three senatorial districts and thirty three local Government areas with Ibadan as its capital. Six local governments were purposively selected and they are Atiba, Oyo West, Oyo East, Afijio, Akinyele and Iseyin Local Governments. The population of the study consists of all Accountants and Auditors in the selected local governments of Oyo State.

\subsection{Sample Size and Sampling Procedure}

A sample of 105 respondents were selected at random, representing more than half of the entire population. Since it is not possible to cover all the staff in the organizations, the formula suggested by [30] was adopted by the study. The calculation of the sample size will be done as follows:

$$
\mathrm{n}=\mathrm{N} /\left(1+\mathrm{a}^{2} \mathrm{~N}\right)
$$

Where,

$$
\begin{aligned}
& \mathrm{N}=\text { population } \\
& \mathrm{\alpha}=\text { alpha level at } 0.05 \\
& \mathrm{n}=\text { estimated sample size }
\end{aligned}
$$

Furthermore, the research made use of primary sources to collect data and they were analysed using descriptive statistics such as frequency and percentages, tables, charts and chi square analysis. The Five Likert Scales; Strongly Agree (SA), Agree (A), Undecided (UD), Disagree (DA) and Strongly Disagree (SA) was used to analyse this data collected from the respondents.

\section{EMPIRICAL RESULTS AND DISCUSSION}

\subsection{Impact of IPSAS on Corruption Reduction in the Selected Local Governments}

The findings of the result as indicated in Fig 4.1 showed that majority (more than 70 percent) of the respondents agreed that IPSAS gives no room for misappropriation of public fund, reduces diversion of public fund to private purse and reduces mismanagement of public fund. All these points to the fact that IPSAS curbs corruption in public offices and in local government councils. 


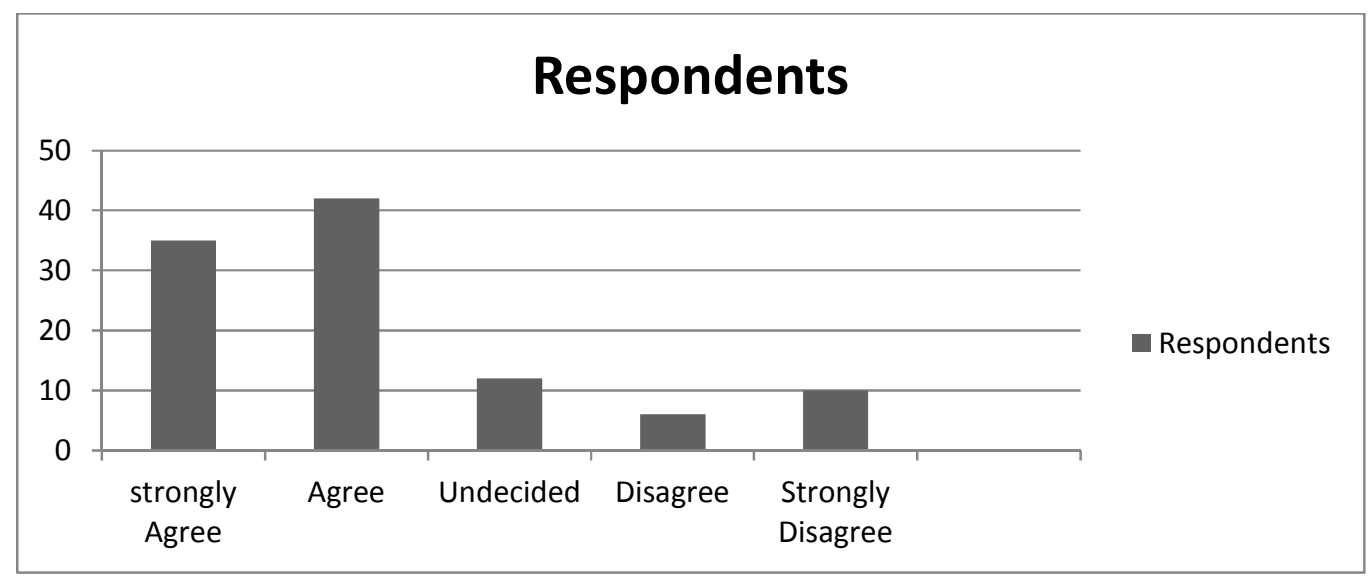

Fig. 4.1. Impact of IPSAS on corruption reduction

Source: Field survey, 2017

Moreover the impact of IPSAS adoption on corruption reduction was tested using chi-square analysis and the result in Table 4.1 revealed ChiSquare measure as 31.091 with a p-value of 0.002 which falls on the rejection region of the hypothesis. Hence, the null hypothesis is rejected since the p-value $=0.002<\alpha=0.05$, assuming a $95 \%$ confidence interval. This clearly showed that IPSAS adoption reduces corruption in the selected local governments of Oyo State.

This finding is corroborated with the report of [31] who posited that incidents of corporate frauds and irregularities such as false financial reporting, irregular transactions, inflated revenues and assets embezzlement which have been on the increase globally could be curbed by the adoption of IPSAS. Moreover, [32] asserted that IPSAS is concerned with the receipt, record keeping, safe keeping and disbursement as well as showing accountability of resources that are under the care of government officials within a given financial year. Thus, this reduces the rate of corruption in public sector organisations.

Furthermore, the findings of the study in Table 4.2 revealed that 80 percent of the respondents agreed that revenue generated by the local government is well accounted for through IPSAS, this showed that IPSAS makes the local government officials to be more accountable and transparent in all their dealings. Moreover, more than half of the respondents agree that with IPSAS, due process is being followed in government expenditure, project awards are well valued and proper records are kept for expenditures. This brings about transparency and accountability in both government revenues and expenditures.

This finding is in conformity with the report of [24], who pointed out that IPSAS are standards of high quality which serve as catalyst for providing sound and transparent financial statements thereby improving operational performance, accountability and fair allocation of resources. In the same vein, Bellanca and Vandernoot [33] confirmed that IPSAS adoption improves transparency and credibility of financial information as it increases efficiency in government activities and ensures full disclosure of necessary material facts and figure in reporting financial transactions of government.

In order to achieve objective 2 of the study which is to to examine the effect of IPSAS adoption on transparency and accountability in government financial reporting activities, Chisquare analysis was used. The result of the analysis as indicated in Table 4.3 indicated that the adoption of IPSAS increases the level of accountability and transparency in the selected

Table 4.1. Chi-square analysis to determine the effect of IPSAS on reduction in corruption

\begin{tabular}{lllll}
\hline Variables & $\mathbf{X}^{2}$ value & df & $\mathbf{P}$ & Decision \\
\hline $\begin{array}{l}\text { Reduction in corruption by public } \\
\text { officers }\end{array}$ & 31.091 & 16 & 0.002 & S \\
No of valid case & 105 & & & \\
\hline \multicolumn{4}{c}{ Source: Field survey, 2017 }
\end{tabular}


Table 4.2. Transparency and accountability in public sector financial reporting in Nigeria

\begin{tabular}{|c|c|c|c|c|c|c|c|c|c|c|c|}
\hline \multirow[t]{2}{*}{$\mathbf{R} / \mathbf{Q}$} & \multirow{2}{*}{$\begin{array}{l}\text { Transparency and } \\
\text { accountability } \\
\text { statement }\end{array}$} & \multicolumn{2}{|r|}{ SA } & \multicolumn{2}{|r|}{ A } & \multicolumn{2}{|r|}{$\mathbf{U}$} & \multicolumn{2}{|c|}{ SD } & \multicolumn{2}{|r|}{ D } \\
\hline & & $F$ & (\%) & $F$ & (\%) & $F$ & (\%) & $F$ & (\%) & $F$ & (\%) \\
\hline 1 & $\begin{array}{l}\text { Revenue generated } \\
\text { are accounted for } \\
\text { through IPSAS }\end{array}$ & 35 & (33.3) & 49 & (46.7) & 2 & (1.9) & 7 & (6.7) & 12 & $(11.4)$ \\
\hline 2 & $\begin{array}{l}\text { All revenue collected } \\
\text { by government are } \\
\text { budget for all } \\
\text { budgeted revenue } \\
\text { collected. }\end{array}$ & 20 & (19.0) & 31 & (29.5) & 17 & (16.2) & 11 & (10.5) & 26 & $(24.8)$ \\
\hline 3 & $\begin{array}{l}\text { The exact amount } \\
\text { incurred by } \\
\text { government are what } \\
\text { being accountable }\end{array}$ & 18 & (17.1) & 35 & (33.3) & 14 & (13.3) & 21 & $(20.0)$ & 17 & (16) \\
\hline 4 & $\begin{array}{l}\text { There are no } \\
\text { leakages in } \\
\text { government revenue }\end{array}$ & 8 & (7.6) & 21 & (20.0) & 13 & (12.4) & 28 & (26.7) & 35 & (33.3) \\
\hline 5 & $\begin{array}{l}\text { Due process in } \\
\text { followed in } \\
\text { government } \\
\text { expenditure }\end{array}$ & 20 & $(19.0)$ & 40 & (38.1) & 6 & (5.7) & 6 & (5.7) & 33 & (31.4) \\
\hline 6 & $\begin{array}{l}\text { Project awards are } \\
\text { well valued }\end{array}$ & 16 & (15.2) & 42 & (4.0) & 14 & (13.3) & 9 & ( 8.6) & 24 & $(22.9)$ \\
\hline 7 & $\begin{array}{l}\text { Proper records are } \\
\text { kept for expenditures }\end{array}$ & 23 & (21.9) & 48 & $(45.7)$ & 10 & $(9.5)$ & 10 & $(9.5)$ & 14 & (13.3) \\
\hline 8 & $\begin{array}{l}\text { Government advance } \\
\text { payment are } \\
\text { accounted } \\
\text { adequately }\end{array}$ & 16 & (15.2) & 46 & $(43.8)$ & 5 & $(4.8)$ & 10 & (9.5) & 28 & (26.7) \\
\hline 9 & $\begin{array}{l}\text { Better use of public } \\
\text { resources are } \\
\text { encouraged by } \\
\text { IPSAS }\end{array}$ & 36 & (34.3) & 49 & (46.7) & 10 & (9.5) & 4 & (3.8) & 6 & $(5.7)$ \\
\hline
\end{tabular}

Source: Field survey, 2017

local governments since the Chi-Square measure obtained is 27.995 with $p$-value of 0.032 which falls on the rejection region of the hypothesis. Hence, the null hypothesis is rejected since the p-value $=0.032<\alpha=0.05$, assuming a $95 \%$ confidence interval. Thus, IPSAS adoption helps to promote transparency and accountability in the selected local governments in Oyo State.
This result tallied with the findings of [5] who reported that IPSAS standards improve transparency and accountability in government entity's financial report. Also, [4] butressed this assertion by concluding that there are no doubts that applying IPSAS can promote efficiency, transparency which in long-run promotes public accountability.

Table 4.3. Chi- square analysis to examine the effect of IPSAS on transparency and accountability in government financial reporting activities

\begin{tabular}{lllll}
\hline Variables & $\mathbf{X}^{2}$ value & df & $\mathbf{P}$ & Decision \\
\hline $\begin{array}{l}\text { Transparency and accountability } \\
\text { in public sector }\end{array}$ & 27.995 & 16 & 0.032 & 5 \\
No of valid case & 105 & & & \\
\hline
\end{tabular}




\section{CONCLUSION AND RECOMMENDA- TION}

The study sought to evaluate the impact of IPSAS on financial accountability of selected local governments in Oyo State, Nigeria. The result of the study showed that adoption of IPSAS increases the level of accountability, transparency and reduces corruption in the selected local governments.

Hence, it is concluded that the adoption of IPSAS in Nigeria is expected to impact positively on operating procedures, reporting practices and hence strengthen good governance and relations with both the government and the governed. Based on the findings of the study, the following recommendations were made:

i. Government at all levels should as a matter of necessity embark on continuous training and retraining of accounting personnel who are charged with the responsibilities of preparing the account in order to maintain and sustain enhanced credibility of financial statements by the public sector entities.

ii. The Federal Government should enact an enabling law to back up the adoption and implementation of IPSAS and more importantly institute appropriate sanctions to ensure full compliance.

\section{COMPETING INTERESTS}

Authors have declared that no competing interests exist.

\section{REFERENCES}

1. Uwujaren W. EFCC Press Release: EFCC arraigns former Oyo State head of service, others for N5.6bn pension scam; 2013.

Available:http://saharareporters.com

2. Alechenu J, Ameh J, Adetayo O, Ogundele K. \$1.6 million BMW EFCC, ICPC Scared to probe Oduah; 2013.

Available:http://saharareporters.com

3. Appah E, Appiah KZA. Fraud and development of sound financial institutions in Nigeria. Nigerian Journal for Development Research. 2010;1(1):49-56.

4. Bello S. Fraud prevention and control in Nigerian public service: The need for a dimensional approach. Journal of Business Administration. 2001;1(2):118-133.
5. Chan IJ. International public sector accounting standards: Conceptual and institutional issues; 2008.

Available:http://jameslchan.com/papers/Ch anCagSem5.pdf

(Retrieved July 2, 2010)

6. Carlin TM. Debating the impact of accrual accounting and reporting in the public sector. Financial Accountability \& Management. 2005;21(3):309-336.

7. IFAC, Policy Position Public Sector Financial Management Transparency \& Accountability, Institute of Internal Auditors (1971). Responsibilities of Internal Auditors; 2012.

8. Adebayo PA. International public sector accounting standard: A practical guide to reporting entities in Nigeria. Arogbodo Press Ltd. Printing and Publishing Area 1, Garki- Abuja. 2013;207.

9. Labode ST. The international public sector accounting standards (IPSAS); 2014.

10. Ezejelue AC. A primer on international accounting. Publish by Clearprint Publishing, Aba, Abia State Nigeria; 2008.

11. Achua JK. Reinventing governmental accounting for accountability assurance in Nigeria. Nigeria Research Journal of Accountancy. 2009;1(1):1-16.

12. Aliyu A, Balaraba A. IPSASs and financial and financial reporting in Nigeria: Answer to implementation questions. Journal of Economics and Finance (IOSR - JEF). 2015;6(6)Ver111.28-32.

13. Adejola PA. IPSAS: A practical work book, rainbow prints, Abuja, Nigeria; 2013.

14. Adejola PA. International public sector accounting standards: Practical implementation guide. Rainbow Prints, Abuja - Nigeria; 2012.

15. Adamu SA, Ahmed AD. IPSAS and Nigerian public sector: The challenges of first time adopters. International Journal of Social Sciences and Humanities Innovations. 2014;2(1):151-160.

16. Barton $A$. The use and abuse of accounting in the public sector financial management reform program in Australia. ABACUS. 2009;5(2):221-248.

17. Baboojee B. Improving service delivery through changing from cash to accrual accounting: Lessons for South Africa based on a cross-national study. Research report presented in partial fulfillment of the requirements for the degree of Master of Development Finance at the University of Stellenbosch; 2011. 
18. Adegite EO. Accounting, accountability and national development. Nigerian Accountant. 2010;43(1):56-64.

19. ljeoma NB. The impact of IPSAS on reliability, credibility and integrity of financial reporting in state government administration in Nigeria. International Journal of Technology Enhancements and Emerging Engineering Research. 2014;2(3). ISSN 2347-4289.

20. Johnson IE. Public sector accounting and financial control. Lagos: Financial Institutions Training Centre; 2014.

21. Cook BJ. Politics, political leadership and public management. Public Administration Review. 1998;58(3):225.

22. Onochie VO. Enhancing financial accounting in government parastatals: A necessity for national development. The Nigeria Accountant, Journal of the Institute of Chartered Accountant of Nigeria. 2006; 39(3).

23. International Federation of Accountants. Governance in the public sector: A governing body perspective. International Public Sector Study; 2001.

Available: http://www.ifac.org

(Retrieved on 2/4/2011)

24. Ohaka J. Dagogo DW, Lenakpe - Op BJ. International Public sector Accounting Standards (IPSAS) and local government financial management in Nigeria. Journal of Accounting and Finance Management. 2016;2(3).

25. Bello A. IPSAS: Issues, Challenges and Implementation. A paper presented at MCPD organized by Institute of Certified public Accountants of Nigeria (ICPAN); 2013.
26. Amaefule LI, Iheduru NG. Electronic accounting system: A tool for checkmating corruption in the Nigerian public sector and a panacea for the nation"s poor economic development status. Sky Journal of Business Administration and Management. 2014;2(4):019-028.

27. Nweze A, Using IPSAS to drive public sector accounting. Journal of Institute of Chartered Accountants of Nigeria. 2013; 46(1):18-22.

28. Khan A, Seiwald J, Schaik FV, IPSAS in Iceland: Towards enhanced fiscal transparency. International Monetary Fund, Publication Services PO Box 92780, Washington, D.C. 20090; 2014.

29. Federal Office of Statistics Nigeria Human Development Report (NHDR) Draft report, Lagos, Nigeria; 1996.

30. Israel G. Determining sample size. University of Florida, IFAS Extension; 2009.

Available: http://edis.ifas.ufl.edu/pd006 (Retrieved on 22/4 2011)

31. Chen MC. The influence of workplace spirituality on motivations for earnings management: A study in Taiwan"s hospitality industry. Journal of Hospitality Management and Tourism. 2012;3(1):1-11.

32. Kara E. Financial analysis in public sector Ac-counting. An Example of EU, Greece and Turkey. Eur J Sci Res. 2012;69(1): 81-89.

33. Bellanca S, Vandernoot J. Analysis of belgian public accounting and its compliance with International Public Sector Accounting Standards (IPSAS) 1, 6, and 22. International Journal of Business and Management. 2013;8(9):122-133.

(c) 2017 Ademola et al.; This is an Open Access article distributed under the terms of the Creative Commons Attribution License (http://creativecommons.org/licenses/by/4.0), which permits unrestricted use, distribution, and reproduction in any medium, provided the original work is properly cited.

Peer-review history:

The peer review history for this paper can be accessed here: http://sciencedomain.org/review-history/19331 